explanation) and mathematics is not excluded. Nevertheless, the serious student of experimental biology, prepared to consult other works in parallel, will not regret the effort.

\section{GENERAL UROLOGY}

By D. R. Sмiтh, M.D. Pp. 326, illustrated. Los Altos: Lange Medical Publications. I 957. $\$ 4.50$.

This is an American book printed so as to resemble typescript. The author states in his preface that the book is written for the medical student and general practitioner not specializing in urology. It is questionable as to how many readers of these categories in this country will wish to read a fairly long monograph on urology, much of the material being covered in textbooks of general surgery.

Those who do read it will, however, be well rewarded, as it is an excellent book within its selfimposed limitations, giving a very rational, complete and well-balanced account of urological pathology, symptomatology and methods of investigation. Methods of treatment, particularly when these are surgical, are covered less adequately, befitting the aim of the book.

\section{OPERATIVE SURGERY}

\section{Volume III-Rectum and Anus. Thorax}

Edited by Charles Robb, M.C., M.Chir., F.R.C.S., and Rodney Smith, M.S., F.R.C.S. Pp. xii + 2 I 5, illustrated. London: Butterworth \& Co. Ltd. I957. £5 ros.

This volume continues the very high standard of its predecessors in both subject matter and style of presentation. It contains Parts IV and $\mathrm{V}$ of the complete work, the former dealing with rectal surgery and the latter with thoracic surgery. The staff of St. Mark's Hospital have for several generations enjoyed a world-wide reputation for the lucid teaching of the practice of rectal surgery and LloydDavies, Lockhart-Mummery and Professor Goligher (lately at St. Mark's) give fresh support to this tradition in their admirable chapters. The contributions by the other three authors to this part are equally valuable.

The sections dealing with thoracic surgery are written by a larger number of authors, but the standard is also uniformly high. The section on cardiac arrest is refreshingly simple and should be read by surgeons who operate on any part of the body. There would seem to be a good case for incorporating this section in the first volume dealing with surgical technique.

This volume confirms the impression left after reading the first two volumes that the complete work will be the standard reference on operative surgery for norny years to come.

\section{AN ATLAS OF MUSCLE PATHOLOGY IN NEUROMUSCULAR DISEASES}

By J. Godwin Greenfield, M.D., G. Milton Shy, M.D., Ellsworth C. Alvord, JR., M.D., and LeONARD Berg, M.D. Pp. ix + I04, with 93 illustrations, many in colour. Edinburgh: E. \& S. Livingstone Ltd. 1957. 45 s.

The illustrations in this book are very good. But it is not just an atlas; it is a genuine piece of original work. Everyone interested in the histology and pathology of muscle will find it indispensable.

D.M.P.

\section{PULMONARY EMPHYSEMA}

Edited by A. L. Barach, M.D., and H. A. Bickerman, M.D. Pp. $\mathrm{x}+545$, with $\mathrm{I} 85$ illustrations. London: Bailliere, Tindall \& Cox Ltd. 1956. 8os.

Physicians in this country would greatly appreciate a clear, concise and authoritative review of the problem of pulmonary emphysema and bronchitis. Under the editorship of Professor A. L. Barach and Dr. H. A. Bickerman I 8 experienced investigators in this field have combined to produce a textbook which aims to fill this need. That this effort has not been entirely successful should not obscure the fact that this book is probably the best available source of up-to-date information on emphysema. The problem is approached in a contemporary manner with proper emphasis upon the pathological physiology of the bronchi, lung parenchyma and skeletal structures. The role of infections is inadequately discussed as far as British needs are concerned, but possibly infection is of less importance in the United States. A further difference is the use of intermittent positive pressure breathing and ' exsufflation,' combined with aerosol therapy, for the treatment of acute and chronic respiratory failure. In this country greater use would be made of tracheotomy (not mentioned), combined with mechanical respirators, either with or without a negative pressure phase.

The metabolic aspects of acute and chronic respiratory failure are only briefly discussed and the recent work on the reaction between ${\mathrm{p} . \mathrm{Co}_{2}}_{2}$ and bicarbonate reabsorption by the kidneys is not mentioned. Nevertheless, the book contains a great amount of valuable information and no doubt will be widely read by those interested in the care of patients with emphysema.

\section{MATERIA MEDICA AND PHARMACOLOGY FOR NURSES}

By J. S. Peel, M.P.S. Second edition. Pp. I72, with I4 diagrams. Christchurch, New Zealand: N. M. Peryer Limited. 1957. 24s.

A second edition of this well-known book is most welcome, presenting the most up-to-date text for student nurses. 